\title{
Assesment of Physical Value Kampung Batik Jetis Towards Sustainable Heritage Development
}

\author{
Fairuz Mutia $^{1}$, Endang Titi Sunarti D. ${ }^{1}$, Ima Defiana ${ }^{1}$
}

\begin{abstract}
Sidoarjo, like other cities in Indonesia also has the old town area. It is taken up by the Government of Sidoarjo with a tourism development plan regarding this potential object. Kampung Batik Jetis while being part of the old town area has the potential value for long occupancy also has the good value for becoming a cultural tourism, namely batik. However, the condition of Kampung Batik Jetis currently eligible to become a tourist destination. In fact, Kampung Batik Jetis is a tourist village that has the potential to be enjoyed on foot toward the batik's gallery, the batik's workshop, the food court area while enjoying the beauty of the old buildings there. This study aims to explore the physical aspects of Kampung Batik Jetis, related to the movement by the residents and tourists.
\end{abstract}

Keywords-Kampung Batik Jetis, Visual-Spatial Value, Walkability, Sustainability.

\section{INTRODUCTION}

Sidoarjo city, like other cities also have the old city area, which is on Jl. Gajah Mada. The development of this Old City is making this area as a tourist magnet. Access is no longer only from land, but will also come from the river corridor that passes through Kampung Batik Jetis and Sidoarjo Old City. It has a positive impact on the development of tourist areas in the area.

The potential old style-residential in this village coupled with the cultural tourism in the form of batik making Kampung Batik Jetis deserve to become the icon and main object for travelers if they visit Sidoarjo. In fact, Kampung Batik Jetis is a tourist village that has the potential to be enjoyed on foot toward many kind of tourism objects, such as batik gallery, batik workshop, and also taking a break in a food area.

According to this kind of street-walking-tourism ideas, Kampung Batik Jetis should be able to sustainably survive, by accomodates all of the needs not only from the tourist, and also the people that lives in there. By using this, we need to know how about the legibility of the Kampung Batik Jetis to became a street-walking tourism spot. This kind of assesment can be held by the communities, beside the researcher. Some other forms of participation that can be participated in the participation in consultation, where the community provides development advice for the village.

\footnotetext{
${ }^{1}$ Fairuz Mutia, Endang Titi Sunarti D., Ima Defiana are with Department of Architecture Faculty of Civil Engineering and Planning, Institut Teknologi Sepuluh Nopember (ITS), Kampus ITS Sukolilo, Surabaya 60111, Indonesia. E-mail: fairuz.mutia@gmail.com; endar@arch.its.ac.id; may.d@arch.its.ac.id.
}

\section{LITERATURE REVIEW}

Walkability is an important concept in a sustainable urban design approach. It is a measure of how friendly an area is for its pedestrians. Walkability has many benefits for health, the environment and the economy [1]. This can be measured through a comprehensive assessment of the infrastructure available to pedestrians and the study linking demand and supply [2]. Walkability itself mentions several aspects of the assessment consisting of 5 parts of conspicuous, convinient, comfortable, convivial, and connected [3]. Kampung Batik Jetis need this kind of benefits for developing itself as a tourism destination object, regarding it's visual as a townscape [4][5].

\section{METHODS}

Walkthrough analysis is used to analyze the data relating to visual and spatial character of the area. User's comfort level obtained by distributing questionnaires to 60 participant consisting of people living in kampung and tourists to know the 5 value of walkability (conspicuous, convinient, comfortable, convivial, connected) representing the level of user comfort room.

A parameter is generated from Grant to determine the aspects to be studied and surveyed. Based of the aspects, the questionnare were made for respondents who have been in accordance with the definition of operations. The responents have to answer questions and problems that exist.

There were 60 respondents with $10 \%$ data from $\pm 300 \mathrm{KK}$ RW 03 (Demography RW 03 Lemahputro District) living in Kampung Batik Jetis (batik craftsmen, batik seller, longholder resident, Jetis community) of 30 people. The number of visitors equated to the number of respondents (30 people) in order to obtain a balanced value.

Value scale is used to facilitate quantitative data output and can be used ad a reference for the analysis process. The value 1 - 5 where the explanation of numbers is as follows:
A) 1 = Very Not Good / Very Not Easy / Very Unclear
B) 2 = Not Good / Not Easy / Not Clear
C) $3=$ Less Good $/$ Less Easy $/$ Less Clear
D) $4=$ Good / Easy / Clear
E) 5 = Very Good / Very Easy / Very Clear

There are 9 segment blocks (see figure 1 below) area in accordance with the majority of human movements occurring in the region. It is used to see the visual aspect of visual and spatial area. 


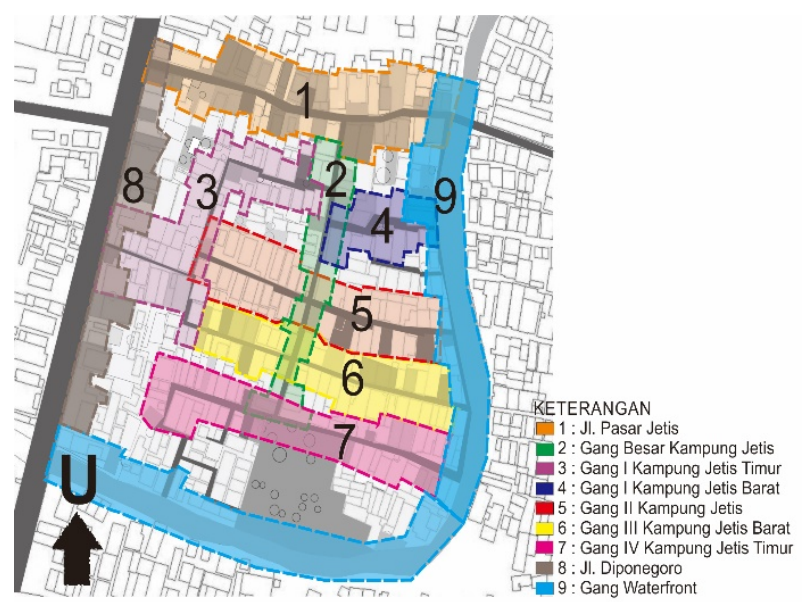

Figure 1. The classification of Research Segments

The results of recorded data is analyzed by synchronic reading and character appraisal to combine the walkthrough analysis held by the researcher. The linkage of data will generate leads that accommodate foot travel comfort, both visually and spatially

\section{RESULTS AND DISCUSSION}

Broadly speaking, according to the respondents it can be seen that the average in the five aspects has not been great.

TABLE 1.

CONSPICUOUS ANALYSIS

\begin{tabular}{|c|c|c|c|}
\hline \multicolumn{4}{|c|}{ CONSPICUOUS ANALYSIS } \\
\hline $\begin{array}{l}\tilde{U} \\
\text { के } \\
\text { के }\end{array}$ & Definition & $\begin{array}{l}\text { Preference in } \\
\text { Grant (2007) }\end{array}$ & Analysis \\
\hline \multirow{3}{*}{ 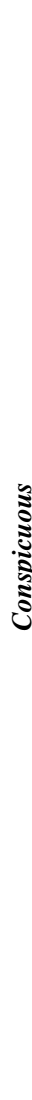 } & \multirow{3}{*}{$\begin{array}{l}\text { The extent to } \\
\text { which } \\
\text { walking in } \\
\text { this kampung } \\
\text { and public } \\
\text { space is } \\
\text { considered } \\
\text { clear and } \\
\text { invites } \\
\text { tourists to } \\
\text { enjoy the } \\
\text { facilities that } \\
\text { exist, } \\
\text { especially } \\
\text { how people } \\
\text { find a } \\
\text { particular } \\
\text { tourist } \\
\text { attractions }\end{array}$} & $\begin{array}{l}\text { Do you think the } \\
\text { area of Kampung } \\
\text { Batik Jetis is quite } \\
\text { easy and good to } \\
\text { pass? }\end{array}$ & $\begin{array}{l}\text { Respondents stated } \\
\text { that the area of } \\
\text { Kampung Batik Jetis } \\
\text { is still not easy and } \\
\text { good to pass (mean = } \\
3,26 \text { ). This is because } \\
\text { the chaotic circulation } \\
\text { between pedestrians, } \\
\text { motorcyclists and cars } \\
\text { crossing the road that } \\
\text { is only } 4 \mathrm{~m} \text { wide plus } \\
\text { the presence of street } \\
\text { vendors who interfere }\end{array}$ \\
\hline & & $\begin{array}{l}\text { Is the arrangement } \\
\text { of billboards, } \\
\text { vegetation, road } \\
\text { signs and } \\
\text { signboards in } \\
\text { buildings and } \\
\text { areas is enough to } \\
\text { make you } \\
\text { recognize the area } \\
\text { of Kampung Batik } \\
\text { Jetis? }\end{array}$ & $\begin{array}{l}\text { With an average rating } \\
\text { of } 3.3 \text { (less well) } \\
\text { respondents stated that } \\
\text { the arrangement of } \\
\text { billboards or other } \\
\text { signage is less able to } \\
\text { help them to recognize } \\
\text { and understand } \\
\text { Kampung Batik Jetis. }\end{array}$ \\
\hline & & $\begin{array}{l}\text { Is the lighting } \\
\text { sufficient to } \\
\text { observe billboards } \\
\text { and signboards so } \\
\text { you know you are } \\
\text { in Kampung Batik } \\
\text { Jetis? }\end{array}$ & $\begin{array}{l}\text { With an average rating } \\
\text { of } 3.06 \text { (less well) } \\
\text { respondents stated that } \\
\text { lighting especially at } \\
\text { night time is less able } \\
\text { to help them to } \\
\text { recognize the area of } \\
\text { Kampung Batik Jetis. }\end{array}$ \\
\hline
\end{tabular}

However, the conspicuous aspect of the clarity of the area [3] is quite high, almost touching the number 3.5 where the number 4 is good. Most feel that their level of comfort in accessing the village area has not been so high. This is influenced by several aspects, namely related to the low level of clarity of the area, especially for respondents who are not domiciled in Kampung Batik Jetis.

TABLE 2.

COMFORTABLE ANALYSIS

\begin{tabular}{|c|c|c|c|}
\hline $\begin{array}{l}\tilde{D} \\
\text { के } \\
\frac{\pi}{4}\end{array}$ & Definition & $\begin{array}{l}\text { Preference in } \\
\text { Grant (2007) }\end{array}$ & Analysis \\
\hline \multirow{3}{*}{ 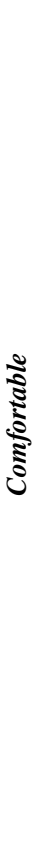 } & \multirow{3}{*}{$\begin{array}{l}\text { The extent } \\
\text { to which } \\
\text { the } \\
\text { activities of } \\
\text { "walking } \\
\text { tours" } \\
\text { accommoda } \\
\text { ted and } \\
\text { facilitated } \\
\text { by } \\
\text { Kampung } \\
\text { Batik Jetis }\end{array}$} & $\begin{array}{l}\text { Do you think the } \\
\text { area of Kampung } \\
\text { Batik Jetis has } \\
\text { good road } \\
\text { condition, high } \\
\text { quality and well } \\
\text { maintained? }\end{array}$ & $\begin{array}{l}\text { With an average rating } \\
\text { of } 2.68 \text { respondents } \\
\text { responding negatively } \\
\text { on road conditions that } \\
\text { are still many holes and } \\
\text { not well maintained }\end{array}$ \\
\hline & & $\begin{array}{l}\text { Do you think the } \\
\text { area of Kampung } \\
\text { Batik Jetis has } \\
\text { adequate street } \\
\text { furniture (lamps, } \\
\text { benches, garbage } \\
\text { cans, shade } \\
\text { plants)? }\end{array}$ & $\begin{array}{l}\text { With an average score } \\
\text { of } 2.61 \text { (disagree) } \\
\text { respondents respond } \\
\text { negatively on road } \\
\text { conditions that are still } \\
\text { minimal to adequate } \\
\text { street furniture thus } \\
\text { reducing their comfort } \\
\text { level }\end{array}$ \\
\hline & & $\begin{array}{l}\text { Do you think the } \\
\text { area of Kampung } \\
\text { Batik Jetis has the } \\
\text { arrangement of } \\
\text { trees and shrubs } \\
\text { that interest you? }\end{array}$ & $\begin{array}{l}\text { With an average score } \\
\text { of } 2.48 \text { (disagree) the } \\
\text { respondents complained } \\
\text { about vegetation } \\
\text { arrangement in the area } \\
\text { of Kampung Batik Jetis } \\
\text { which is still considered } \\
\text { minimal }\end{array}$ \\
\hline
\end{tabular}

In the comfortable aspect also does not meet the aspects described [3]. This makes them less comfortable exploring the area of the village, plus the lack of greening and vegetation that makes hot and no shade.

TABLE 3.

CONVINIENT ANALYSIS

\begin{tabular}{|c|c|c|c|}
\hline $\begin{array}{l}\tilde{U} \\
\mathbb{\varpi} \\
\text { ñ }\end{array}$ & Definition & $\begin{array}{l}\text { Preference in } \\
\text { Grant (2007) }\end{array}$ & Analysis \\
\hline \multirow[t]{2}{*}{ 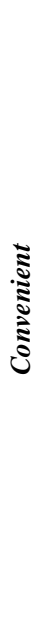 } & \multirow{2}{*}{$\begin{array}{l}\text { The extent } \\
\text { to which } \\
\text { the walk } \\
\text { becomes } \\
\text { easy and } \\
\text { facilitated } \\
\text { so as to } \\
\text { compete } \\
\text { with other } \\
\text { modes of } \\
\text { transportati } \\
\text { on in terms } \\
\text { of } \\
\text { efficiency } \\
\text { (in time, } \\
\text { money and } \\
\text { space) to } \\
\text { visit the } \\
\text { Kampung }\end{array}$} & $\begin{array}{l}\text { Do you think the } \\
\text { area of Kampung } \\
\text { Batik Jetis has a } \\
\text { good arrangement } \\
\text { in terms of traffic } \\
\text { signs and public } \\
\text { vehicles so you } \\
\text { feel fast in } \\
\text { reaching the } \\
\text { destination in } \\
\text { Kampung Batik? }\end{array}$ & $\begin{array}{l}\text { Respondents gave a } \\
\text { fairly good impression } \\
\text { (mean = 3.06) on the } \\
\text { traffic signs } \\
\text { arrangement to easily } \\
\text { access the area of } \\
\text { Kampung Batik Jetis } \\
\text { from the main line of the } \\
\text { city }\end{array}$ \\
\hline & & $\begin{array}{l}\text { Do you think the } \\
\text { area of Kampung } \\
\text { Batik Jetis has } \\
\text { good road } \\
\text { arrangement and } \\
\text { traffic flow? }\end{array}$ & $\begin{array}{l}\text { With an average rating } \\
\text { of } 2.63 \text { (disagree) } \\
\text { respondents responded } \\
\text { negatively to road } \\
\text { arrangement and traffic } \\
\text { flows and also stated } \\
\text { that they are quite } \\
\text { difficult to access the }\end{array}$ \\
\hline
\end{tabular}




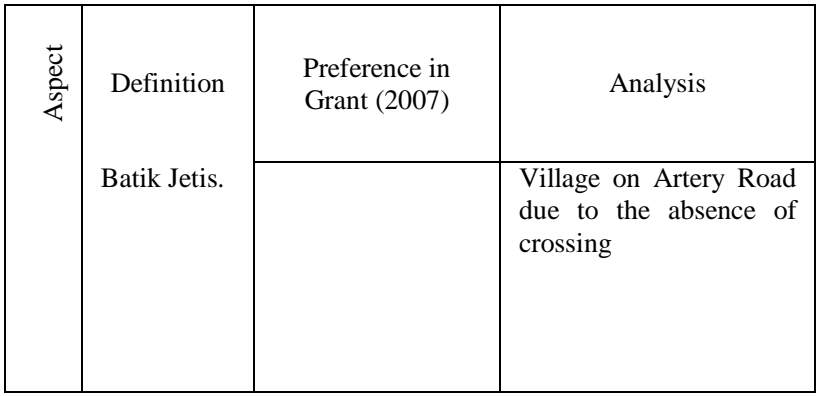

In the convinient aspect also found the value between 2.5 to 3 . Respondents still prefer to use the vehicle as an alternative to move within the area of Kampung Batik Jetis. This was felt by the respondents as a form of inconvenience on foot because they felt that walking was troubling for them to access the kampung area.

TABLE 4.

CONVIVIAL ANALYSIS

\begin{tabular}{|c|c|c|c|}
\hline 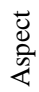 & Definition & $\begin{array}{l}\text { Preference in } \\
\text { Grant (2007) }\end{array}$ & Analysis \\
\hline \multirow{2}{*}{ 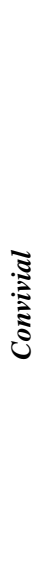 } & \multirow{2}{*}{$\begin{array}{l}\text { The extent } \\
\text { to which } \\
\text { walking is a } \\
\text { fun activity, } \\
\text { in terms of } \\
\text { interacting } \\
\text { with } \\
\text { people, } \\
\text { artificial } \\
\text { and natural } \\
\text { environmen } \\
\text { ts, as well } \\
\text { as other } \\
\text { road users. }\end{array}$} & $\begin{array}{l}\text { Do you think the } \\
\text { area of Kampung } \\
\text { Batik betis } \\
\text { "friendly" by } \\
\text { accommodating } \\
\text { every need of road } \\
\text { users both old and } \\
\text { young and also } \\
\text { disabled? }\end{array}$ & $\begin{array}{l}\text { The mean value } \\
\text { indicates a value of } \\
2.36 \text { which indicates } \\
\text { that respondents still } \\
\text { lack access to } \\
\text { transportation and } \\
\text { intermodal facilities in } \\
\text { the area }\end{array}$ \\
\hline & & $\begin{array}{l}\text { Do you think the } \\
\text { area of Kampung } \\
\text { Batik Jetis } \\
\text { provides access to } \\
\text { public } \\
\text { transportation for } \\
\text { you to enjoy batik } \\
\text { tour area? }\end{array}$ & $\begin{array}{l}\text { The mean value } \\
\text { indicates a value of } \\
2.28 \text { which shows that } \\
\text { respondents do not get } \\
\text { access to public } \\
\text { transportation to enjoy } \\
\text { the atmosphere of } \\
\text { Kampung Batik Jetis }\end{array}$ \\
\hline
\end{tabular}

The convivial aspect is also very lacking in this area. The majority of respondents gave a negative response on this aspect because it did not meet the elaboration [3] about how fun and pedestrian-friendly walking activities are. Respondents complained that there were no visually visible sights, whereas so many older buildings existed [4][5].

In the connected aspect is also found the value between 2.5 to 3. Majority respondents said the lack of access to the mode to get and enjoy Kampung Batik Jetis. But there are 2 dichotomies, namely for the people of Kampung Batik Jetis domicile they feel that the connected aspect is good but respondents who are not domiciled in this village can not easily change the mode.

TABLE 5.

CONNECTED ANALYSIS

\begin{tabular}{|c|c|c|c|}
\hline 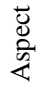 & Definition & $\begin{array}{l}\text { Preference in } \\
\text { Grant (2007) }\end{array}$ & Analysis \\
\hline 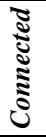 & $\begin{array}{l}\text { The } \\
\text { availability } \\
\text { of good } \\
\text { connections }\end{array}$ & $\begin{array}{lr}\text { Do you think the } \\
\text { area of Kampung } \\
\text { Batik retis } \\
\text { provides r public }\end{array}$ & $\begin{array}{l}\text { The mean value } \\
\text { indicates a value of } \\
2.36 \text { which indicates } \\
\text { that respondents still }\end{array}$ \\
\hline
\end{tabular}

\begin{tabular}{|c|c|c|c|}
\hline 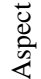 & Definition & $\begin{array}{l}\text { Preference in } \\
\text { Grant (2007) }\end{array}$ & Analysis \\
\hline & \multirow{2}{*}{$\begin{array}{l}\text { to public } \\
\text { transport and } \\
\text { other key } \\
\text { destinations } \\
\text { related to the } \\
\text { area of } \\
\text { Kampung } \\
\text { Batik Jetis }\end{array}$} & $\begin{array}{l}\text { transportation } \\
\text { access for you to } \\
\text { get there? }\end{array}$ & $\begin{array}{l}\text { lack access to } \\
\text { transportation and } \\
\text { intermodal facilities in } \\
\text { the area }\end{array}$ \\
\hline & & $\begin{array}{l}\text { Do you think the } \\
\text { area of Kampung } \\
\text { Batik Jetis } \\
\text { provides access to } \\
\text { public } \\
\text { transportation for } \\
\text { you to enjoy batik } \\
\text { tour area? }\end{array}$ & $\begin{array}{l}\text { The mean value } \\
\text { indicates a value of } \\
2.28 \text { which shows that } \\
\text { respondents do not get } \\
\text { access to public } \\
\text { transportation to enjoy } \\
\text { the atmosphere of } \\
\text { Kampung Batik Jetis }\end{array}$ \\
\hline
\end{tabular}

Based on respondent's analysis, the result is combine by the physical value in researcher's point of view. Following linear side view and serial view techniques on 9 segments of observation, it was found that there were some visual qualities to be potential on the site, as well as some low visual and spatial qualities but still reinforced by strengthening in physical aspects. The results of the visual and spatial quality readings of this area are summarized in the following analysis conclusions

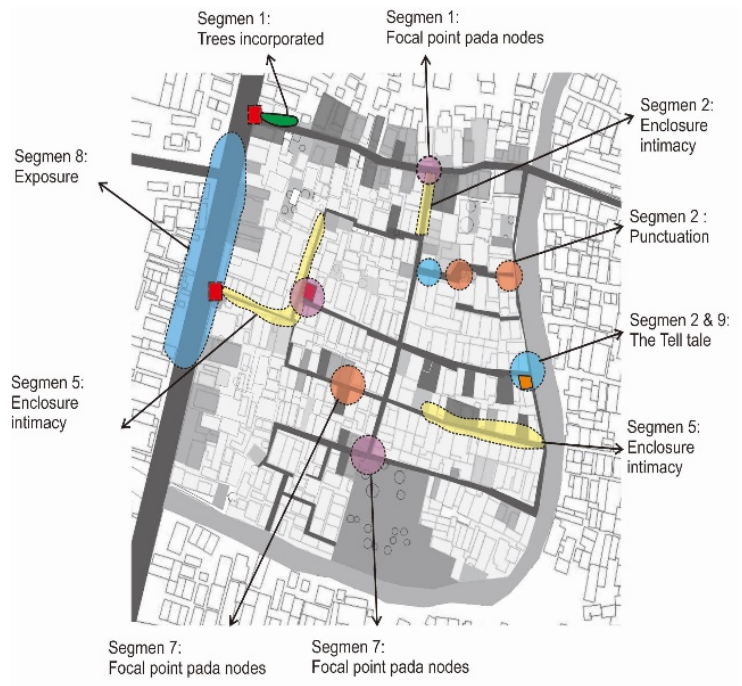

Figure 2. Potential points of Kampung Batik Jetis

\section{CONCLUSION}

The physical potential of the area is very strong. This is due to the strong old building character and the function of batik culture that still adorn the village. In fact, it contradicts with the comfortable aspect especially in 5C elements of walkability. The results of the analysis in the field shows that aspects of walkability is felt less by the public.

This is a really big consideration about how the arrangement of a tourist area and convenience level for travelers to enjoying the scenery. For this reason Kampung Batik Jetis should facilitate the convenience of users of space, namely the visitor and the residents. It includes not only street furniture, road conditions, but also the arrangement of vegetation and adequate. 
This results deeply impact on the sustainability factor of Kampung Batik Jetis as a tourism object, especially emerging as a tourism development area. As to accomodate the community and the tourist, Kampung Batik Jetis needs to be given some areas for supporting heritage development such as plaza or green open space that can be used by residents as a recreational area. Resident are given access to meet their economic needs so that the community will contribute to the sustainability of the village

\section{REFERENCES}

[1] J. Barman and C. Daftardar, "Planning for Sustainable Pedestrian Infrastructure with upcoming MRTS - An Appraisal of Walkability Conditions in Lucknow,” Inst. T. Planners, India J., vol. 7, no. 3, pp. 64-67, 2010.

[2] L. Schipper, J. Leather, and H. Fabian, Transport and Carbon Dioxide Emissions: Forecasts, Options Analysis, and Evaluation. Asian Development Bank, 2009.

[3] J. A Grant \& Associates, "Glenferrie Road Precinct Walkability Study," 2008.

[4] K. Lynch, The Image of the City. Cambridge, Massachusetts: MIT Press, 1960.

[5] G. Cullen, The concise townscape. London: Architectural Press, 1971. 